\title{
Compensation for Violation \\ of the Right to Trial and Execution \\ of a Judicial Act within a Reasonable Time: \\ Russian Experience and Prospects
}

\author{
Inna S. Bogdanova* \\ Siberian Federal University \\ 79 Svobodny, Krasnoyarsk, 660041, Russia
}

Received 20.03.2017, received in revised form 10.04.2017, accepted 24.04.2017

The article is devoted to the implementation of provisions of the Convention for the Protection of Human Rights and Fundamental Freedoms and the decisions of the European Court of Human Rights in the Russian national legal system in terms of modification of the Russian legislation as a result of the adoption of a special law on compensation for violation of the right to trial and execution of a judicial act within a reasonable time. It is alleged that a new statutory concept was introduced into the Russian legislation providing for compensation of a non-property damage inflicted on legal entities, which is not fully consistent with the current civil legislation in Russia.

Keywords: compensation, reasonable time, right to trial, right to execution of a judicial act, nonmaterial damage, implementation, Convention for the Protection of Human Rights and Fundamental Rights and Freedoms, decision of the European Court of Human Rights.

DOI: 10.17516/1997-1370-0094.

Research area: law.

Implementation of the Convention for the Protection of Human Rights and Fundamental Freedoms and the decisions of the European Court of Human Rights in the Russian national legal system is a difficult and lengthy process carried out in various directions, among which the cases of changes in the national legislation with a view to implement the relevant ECHR judgments are of a particular interest.

To date, one of such cases is a completely new institution for the Russian legal system, which compensates for the violation of the applicant's right to trial and execution of a judicial act within a reasonable time. The institution was established on May 4, 2010 in connection with the adoption of the Federal Law No. 68-FZ "On compensation for violation of the right to trial within a reasonable time or the right to execution of a judicial act within a reasonable time" dated April 30, 2010 (hereinafter - the Law of April 30, 2010 No. 68-FZ) ${ }^{1}$, which provides for conditions and a procedure for payment of compensation for citizens and legal entities affected by the violation of their right to trial within a reasonable time.

(c) Siberian Federal University. All rights reserved

* Corresponding author E-mail address: Bogdanov_rabota@mail.ru 
The establishment of the institution was a response to the ECHR's adoption of the first "Pilot Judgment" dated January 15, 2009 in the case of Burdov v. Russia (No. 2), which dealt with the problem of non-enforcement of judgments made on claims against the state and claims providing for the payment from the state budget. At the same time, as noted by the researchers, this decision was a "tough precedent", because here "the national legislator undertook to apply systemic measures to prevent the violation of fundamental rights, to change the rule of law in such a way as indicated by the decision of the international court, i.e. "had to" create a positive legal regulation" 2 .

The past 6 years from the date of entry into force of the above-mentioned law allow us to formulate some conclusions, which could suggest that the Russian legislator, in pursuance of the "ECHR pilot judgment", essentially introduced a fundamentally new mechanism for protecting the rights of victims, which is not fully consistent with the provisions of the Russian civil law.

First of all, the law of April 30, 2010 No. 68FZ only covers cases of violation of a person's right to trial within a reasonable time or the right to execute a judicial act providing for recovery proceedings at the expense of budgets of the budget system of the Russian Federation within a reasonable time. Accordingly, the violation of any other rights that are not related to the decision made by the court or another body in a particular case to resolve it on the merits does not entitle a victim to use the mechanism provided for by this law and is carried out according to the rules of the Civil Code of the Russian Federation.

The law does not disclose the issue of the content of the right to trial within a reasonable time, nor has it been resolved in procedural acts fixing norms on reasonable terms of the relevant type of proceedings. At the same time, the notion of a reasonable time for legal proceedings is not identical with the notion of a period for consideration of a specific case, as evidenced by the provisions of Paragraph 2 of Article 1 of the Law of April 30, 2010 No. 68FZ, by virtue of which the violation of time limits for the consideration of a case per se does not constitute the violation of the right to trial within a reasonable time.

In order to resolve the issue of the reasonableness of the legal proceedings' term in a particular case, it is suggested to take into account such circumstances as the legal and factual complexity of the case, the behaviour of the participants in the process, the sufficiency and effectiveness of the court's actions for the timely consideration of the case and the overall duration of the proceedings.

If, as a result of investigation of these circumstances, the court reviewing the victim's statement comes to a conclusion that the total term of the legal proceedings in a particular case was not reasonable, then it shall have the right to award an appropriate compensation to the victim. In this case, the award of such compensation is not directly related to causing a property and moral damage to the victim, since such a violation may not lead to any obvious adverse consequences. As noted in Paragraph 40 of the Resolution of the Plenum of the Supreme Court of the Russian Federation No. 11 of March 29, 2016", "since the very fact of the violation of the right to legal proceedings within a reasonable time or the right to execution of a judicial act within a reasonable time speaks for an inflicted non-property damage (violation of the right to judicial protection) and its compensation does not depend on the fault of a body or an official, a person who applied for compensation should not prove the existence of this damage".

As a result, it turns out that in order to award a person with a compensation for violation of the right to trial within a reasonable time, there 
is no need to establish the illegality of actions of the relevant state authorities and their officials, since the right to compensation arises because of the very fact of violation of the relevant nonproperty law. In this sense, the mechanism for payment of compensation, as stipulated by the law of April 30, 2010 No. 68-FZ, corresponds to the modern practice of international courts ${ }^{4}$ that, when deciding whether to award compensation to a victim or not, proceed only from assessing the actions of the court and its connection with the victim.

Paragraph 2 of Article 1 of the Law of 30 April 2010, No. 68-FZ stipulates an additional condition for awarding an appropriate compensation, the essence of which is that it can only be obtained by a person if the violation of the right to trial within a reasonable time took place for reasons beyond the control of the person who applied for compensation, except for extraordinary circumstances that are unavoidable under the given circumstances. The establishment of this condition suggests that the competent court would conduct the analysis of not only the materials of a particular case with the applicant's participation, but also the evaluation of the applicant's actions in the judicial proceedings thereon.

At the same time, it should be borne in mind that the determination of the existence or absence of reasons under the control on the victim that have affected the violation of a reasonable period of judicial proceedings will also depend on the case-law of the European Court of Human Rights, since the law directs the courts to follow the practice of the European Court of Human Rights when deciding on the amount of compensation (Paragraph 2, Article 2 of the Law of April 30, 2010 No. 68-FZ). Thus, the European Court of Human Rights has repeatedly noted in its decisions that the applicant cannot be charged with using all means of protection of his/her interests provided by the national legislation. In this regard, the ECHR indicates that the applicant is not liable for those periods when he/she clarifies his/her claims under the lawsuit or tries to obtain additional evidence, so the person uses his/her procedural rights. At the same time, the judicial bodies that did not ensure the promptness of consideration of requests of the parties, who did not take measures to claim evidence, call witnesses, conduct expert examinations and so on, remain responsible for the time limits of the case consideration ${ }^{5}$.

A distinctive feature of the concept stipulated by the Law of April 30, 2010 No. $68-\mathrm{FZ}$ is also the fact that it is based on a completely new legislative concept - the idea of the existence of non-material damage as a special legal category that is different from the moral damage inflicted on a person. In this case, the legislator specifically emphasizes in Paragraph 4 of Article 1 of the Law that the award of compensation for violation of the right to trial within a reasonable time deprives the interested person of the right to compensation of moral damage for these violations, but does not prevent compensation of damage in accordance with Art.1069-1070 of the Civil Code of the Russian Federation.

Taking into account that both citizens and legal entities can act as a victim due to violation of the right to trial within a reasonable time, it should be noted that the Law of April 30, 2010 No. 68-FZ for the first time in the Russian legislation provides for the legal entities the right to compensation of the non-material damage reflecting, therefore, the practice of the ECHR on this issue. And, in this sense, there is a contradiction with the national legislation, since the Paragraph 11 of Article 152 of the Civil Code of the Russian Federation dated October 1, 2013 introduced provisions that directly exclude the possibility of compensation of the moral damage caused to legal entities as a result of violation of 
their non-property right to business reputation. Given that the current civil law does not contain provisions that grant legal entities the right to compensation of the non-material damage as well, the analyzed law is the only normative legal act in the Russian law, where such a right is granted to the said entities, and this issue requires serious consideration.

In addition to the above-mentioned aspects, the institution of compensation for violation of the applicant's right to trial and the execution of a judicial act within a reasonable time did not manage to resolve a number of systemic problems stated in the decisions of the ECHR, since it was initially focused on a narrow sphere of social relations. In particular, problems of execution of judicial acts providing for any obligations of the state of a natural character (provision of housing, transfer of property, etc.) or related to the responsibility of the state for non-execution of judgments by municipal unitary enterprises and other "state-dependent" entities, etc. have been left unreached ${ }^{6}$.

Thus, it should be noted that the studied institution of compensation is essentially an attempt to legally introduce the legal positions of the ECHR in a certain category of cases into the Russian national legislation, which has its shortcomings and requires further comprehension and elaboration.

\footnotetext{
1 On compensation for violation of the right to trial within a reasonable time or the right to execution of a judicial act within a reasonable time: Federal Law of the Russian Federation of April 30, 2010, No. 68-FZ (latest edition) Legislation Bulletin of the Russian Federation, 2010, No.18, Art. 2144.

2 Refer to: Schubert, T.E. (2015). Implementation of the ECHR judgments in the national legislation. Journal of Russian Law, 6.

3 On some issues arising in the consideration of cases of awarding compensation for violation of the right to trial within a reasonable time or the right to execution of a judicial act within a reasonable time: Regulation of the Plenum of the Supreme Council of the Russian Federation of March 29, 2016. No.11.

4 Neshataeva, T.N. (2009). Property liability for damage caused by the state: problems of the judicial practice. Arbitration practice, 9, 67.

Practice of the European Court: letter of the Krasnoyarsk Territory Court dated June 17, 2008.

6 Refer to: Filatova, M.A. (2015). Perfection of domestic legal remedies in the Russian Federation: problems and prospects. Russian Yearbook of the European Convention on Human Rights (issue 1). Moscow: Statut.
}

\title{
Компенсация за нарушение права \\ на судопроизводство и исполнение \\ судебного акта в разумный срок: \\ российский опыт и перспективы
}

\author{
И.С. Богданова \\ Сибирский федеральный университет \\ Россия, 660041, Красноярск, пр. Свободный, 79
}

Статья посвящена проблеме имплементации положений Конвенции о защите прав человека и основных свобод и решений Европейского суда по правам человека в российскую национальную правовую систему на примере изменения национального российского законодательства вследствие принятия специального закона, посвященного выплате компенсации за нарушение права на судопроизводство и исполнения судебного акта в разумный срок. Утверждается, что законом в российское законодательство была введена новая юридическая конструкиия, предусматривающая возмещение неимущественного вреда, причинен- 
ного юридическим лицุам, что не в полной мере согласуется с действующчм гражданским законодательством России.

Ключевые слова: компенсация, разумный срок, право на судопроизводство, право на исполнение судебного акта, нематериальный вред, имплементация, Конвенция о защчите прав человека и основных прав и свобод, решение Европейского суда по правам человека.

Научная специиальноть: 12.00.00 - юридические науки. 